\title{
Classification Study of Ingested Plastic Particles in Marine Organisms using Electron Microscope: A Case Study of Cameroon Beaches
}

\author{
Oben Mbeng L. ${ }^{1 *}$, Mboglen David. ${ }^{1,2} \&$ Ntyanm Ondo S. \\ ${ }^{1}$ The University of Douala, P.O Box 7236, Institute of Fisheries and Aquatic Sciences at Yabassi \\ ${ }^{2}$ Specialized Research Centre for Marine Ecosystems (CERECOMA/ IRAD) at Kribi, Cameroon
}

\begin{abstract}
Plastic wastes are non-biodegradable whose fragmentation often leads to the formation of micro plastics. These are likely to be ingested by marine organisms with grave consequences to human health. A plastic waste classification study was carried out using (Pseudotolithus sp and E. fimbriata) to determine the quantity and quality of ingested plastic particles. It is on this basis that a laboratory analysis was carried out using an electron microscope. From a qualitative and quantitative point of view, plastic debris ingested by organisms (Pseudotolithus sp and E. fimbriata) was classified into five groups: (a) fishing lines (47\%), (b) plastic particles (9\%), (c) cord filaments (23\%) thongs (13\%), and other particles (8\%). The results from this study will certainly enhance policy development where protein from fish is considered the ultimate source for protein for humankind, not forgetting fish pollution which is a common cry to communities that depend on fish for their livelihoods and as an ideal source of protein.
\end{abstract}

Keywords: Plastic Waste Classification, Marine Pollution, Marine Environment, Human Health.

\section{INTRODUCTION}

In the environment, plastic pollution can have several consequences. Aside from the visual pollution they cause, plastics affect marine organisms directly or indirectly at different levels of the food chain [1]. Chemically, plastics are made up of chains of identical sequences (or polymers) of carbon molecules, mainly hydrocarbons, organic molecules toxic to many organisms, liable to accumulate along food chains. In areas of accumulation, the concentration of microplastics observed ( 0.5 to $5 \mathrm{~mm}$ in size) is comparable to that of zooplankton (between $0.005 \mathrm{~mm}$ and more than $50 \mathrm{~mm}$ ). The Mediterranean, for example, has microplastic / zooplankton ratios between $1 / 10$ to $1 / 2$ [2].

The risk for zooplankton predators (i.e. fish) to ingest microplastic is therefore considerable. The residence time of plastic in small pelagic fish is estimated to be between 1 day and 1 year [3]. The fragments of ingested microplastics are found in animal droppings, they can sink with corpses or be transferred to predators and thus reach the upper echelons of the food chain [4]. Plastics are also vectors of dispersal of toxic compounds which can also accumulate in food chains. These compounds can be directly present in the composition of plastics, or else adsorb on their surface. In the first case, they are additives (phthalates, biphenyls) incorporated into certain plastics to increase their resistance. Various studies have shown that these compounds can be toxic to certain animals and humans [5].

Other toxic compounds (hydrocarbons, pesticides, DDT, PCB) can be adsorbed to plastics, which is likely to increase their dispersion, persistence at sea and accumulation in the highest trophic levels [6]. If plastic debris in the environment arouses so much interest, it is mainly because there are many known or suspected impacts.The most obvious [7] are the visual impacts, negative for tourism for example, boating accidents involving large plastic objects (buoys or drift nets) are also more and more numerous. The physical impacts on fauna have been observed for many years, for example in the albatross [8]. Many other species are concerned: [9] list 250 species in which strangulations or ingestions of plastic causing suffocation or obstruction of the digestive tracts have been observed, ranging from penguins to whales, including fish, crustaceans and various birds.

The disastrous effects of ingesting plastic debris mistaken for prey are also well documented, with consequences for the digestive systems of animals such as fish, birds, sea turtles and marine mammals, which can lead to their death [10]. This debris is also considered as a vector for dispersing toxic algae and pathogenic microorganisms [11]. 


\section{MATERIAL AND METHODS}

\subsection{Presentation of the Study area}

The study took place from July 13 to December 5, 2016 at the Specialized Center for Research on Marine Ecosystems (CERECOMA-IRAD of Kribi), located in the Southern Region of Cameroon.

The Kribi continental shelf is approximately $10,600 \mathrm{~km}^{2}$. In the east of the region, the highest relief reaches $300 \mathrm{~m}$. There is an alternation of sandy beaches and metamorphic rocky outcrops, frequently opened by silted estuaries. The relief of the continental shelf is rugged due to rocky banks and sand mounds [12]. Typically, soils in Kribi have an acidic pH, in the order of 4.1. The permeability is high at the surface and decreases with depth, and the organic matter content is of the order of $2 \%$. The variations in the physiognomy of the profiles, in particular with regard to the presence of coarse elements (gravel, ferralitic concretions, blocks of rock) suggests the existence of two types of soil: ocher soils (without coarse elements) and gravelly soils [13].

The climate encountered in the southern region is equatorial, subject to marine influence and the dynamics of the inter tropical fronts receives an average of $2900 \mathrm{~mm}$ of rain in 204 days. There are four seasons: a large rainy season from mid-August to November, a small rainy season from March to June, a large dry season from December to mid-March and a small dry season from June to mid-August [14]. The average temperature in the South is around $25^{\circ} \mathrm{C}$; this value can rise to $28^{\circ} \mathrm{C}$ in the dry season with a peak at $31^{\circ} \mathrm{C}$ in March. Winds are weak $(0.5$ to $2 \mathrm{~m} / \mathrm{s})$. The hydrographic network is dense, with catchments of small rivers (Table I), rocky creeks and rapids and small waterfalls.

Table I: Characteristics of the main rivers of the coastal region of Kribi (Adapted from) [15].

\begin{tabular}{lllll}
\hline River & Lenght $(\mathbf{K m})$ & Watershed $\left(\mathbf{K m}^{2}\right)$ & Average flow $\left(\mathbf{m}^{2} / \mathbf{s}\right)$ & Average flow $\left(\mathbf{m}^{3} / \mathbf{s}\right)$ \\
\hline Nyong & 800 & 14000 & $2,8^{*} 10^{9}$ & 376 \\
Lokoundjé & 216 & 1150 & 28,2 & 118 \\
Kienké & 130 & 1435 & 49,2 & 177 \\
Lobe & 130 & 2305 & 102 & 390 \\
\hline
\end{tabular}

Several types of vegetation are identified on the south coast; they alone are home to more than 1,500 plant species divided into 640 genera and 141 families. The flora is influenced by the climate and we observe a grouping in herbaceous layer, shrub layer and littoral forest. In addition to the six mangrove species present in the Kribi-Campo area, there are also coastal border forests or forests of Avicenniacae, Caesal pinioidae rich in Socoglotis gabonensis, Hibiscus escalentus (Gombo), Dalbergia acastaphyllum, Drepanocarpus lunatus and Arécacae sp (palm trees, coconut trees) [16].

The fauna is very rich and varied depending on the space. This is how we meet terrestrial, aerial and aquatic fauna. The terrestrial fauna consists of mammals, hedgehogs and reptiles; the avian fauna is composed of birds, insects especially bees and the aquatic fauna is mainly composed of molluscs, shrimps, crabs and fish and occasionally sea turtles [12].

\subsection{Marine organisms}

Ingestion of micro plastics by various marine vertebrates and invertebrates in laboratory and field conditions has been reported in the literature [17]. Sampling strategies are numerous and highly dependent on the target organisms, they only give an overview of the control organizations for the ingestion of micro plastics with a focus on the field sampling [1; 18]. Laboratories studying the ingestion of micro plastics by organisms frequently use microscopic plastic beads of known polymer origin, which can be easily identified and counted under the microscope in the contents and excretions of the gut or in the case of the organisms transparent planktonic cells or in the organism itself [19;20]. After dissection, the stomach contents or the entire digestive tract was stored or frozen for later analysis.

\subsection{Sediments and beaches}

Detected worldwide on beaches and in subtidal sediments (Table 2), the extraction method used by the majority of authors was developed [21]. This technique, which is currently the most widely used, relies on the density of a concentrated solution of $\mathrm{NaCl}$ $(1.2 \mathrm{~kg} \mathrm{~L}-1)$ to separate the sediment from the particles of micro plastics. This is because when this salt solution is added to the sediment sample, the low density micro particles float to the surface. However, this method is only effective for polymers with a 
density lower than that of the saturated salt concentration, i.e. $1.2 \mathrm{~g} \mathrm{~cm}^{3}$, and not suitable for the extraction of high density polymers. Plastics such as polyvinyl chloride (density $1.14-1.56 \mathrm{~g} \mathrm{~cm} 3$ ) or polyethylene terephthalate $\left(\right.$ density $1.32-1.41 \mathrm{~g} \mathrm{~cm}^{3}$ ) will not float in the concentrated $\mathrm{NaCl}$ solution. These two polymers, however, account for $18 \%$ of European plastic demand [22] representing a significant proportion of current micro plastics in the marine environment. Particularly in marine sediments, the proportion of these high density plastics may be higher: due to their high density, these types of plastics will tend to sink more easily than lighter plastics.

Table2: Maximum concentration of micro plastics found in sediment [27]

\begin{tabular}{|c|c|c|c|c|}
\hline Country & Location & Max concentration & Unit & Reference \\
\hline India & Ship-breaking yard & 89 & $\mathrm{mg} \mathrm{kg}^{1}$ & [23] \\
\hline UK & Beach $^{\mathrm{a}}$ & 9 & $\mathrm{mg} \mathrm{kg}^{1 \mathrm{~b}}$ & {$[21]$} \\
\hline UK & Estuarine $^{\mathrm{a}}$ & 35 & $\mathrm{mg} \mathrm{kg}^{1 \mathrm{~b}}$ & {$[21]$} \\
\hline UK & Subtidal $^{\mathrm{a}}$ & 86 & $\mathrm{mg} \mathrm{kg}^{1}$ & {$[21]$} \\
\hline Singapore & Beach & 16 & $\mathrm{mg} \mathrm{kg}^{1 \mathrm{~b}}$ & {$[24]$} \\
\hline UK & Sewage disposal site & 15 & $\mathrm{mg} \mathrm{kg}^{1}$ & {$[25]$} \\
\hline Belgium & Harbour & 391 & $\mathrm{mg} \mathrm{kg}^{1}$ & {$[26]$} \\
\hline Belgium & Continental shelf & 116 & $\mathrm{mg} \mathrm{kg}^{1}$ & [26] \\
\hline Belgium & beach & 156 & $\mathrm{mg} \mathrm{kg}^{1}$ & [26] \\
\hline
\end{tabular}

a Only fiber concentrations were reported.

b Original unit (number of fiber $50 \mathrm{~mL} 1$ sediment) converted using an average sediment density of $1600 \mathrm{~kg} \mathrm{\textrm {m } ^ { 3 }}$ [28] and 1.25 as average wet sediment/dry sediment ratio.

\subsection{Water surface}

Due to their relatively low concentrations in the sample, sampling of micro plastic particles generally requires large volumes of control water. Thus, samples from open water are usually taken with plankton nets of different mesh sizes. The sea surface is sampled for micro plastics floating by the Manta trawl net [29] or neuston fillets [30]. While neuston catamarans (fig. 2a) can be operated even in higher waves, a manta trawl (fig. 2b) is used in calm waters. The volume filtered by a net is usually recorded by a flowmeter mounted at the opening, allowing the normalization of the filtered volume and thus a calculation of the concentrations of microplastics (particles / g) per unit volume of water. The relation of concentrations to the area sampled is also possible by multiplying the trawl distance by the horizontal width of the opening. Trawl speed depends on weather conditions and currents, but usually ranges between 1 and 5 knots. The plankton sample is concentrated in the snare at the end of the net, the latter must be thoroughly rinsed from the outside to ensure that all plankton and debris are washed and concentrated in the snare [29]. The contents of the collar are finally transferred to a control container and fixed with plastic friendly fixatives (e.g. formalin) or stored frozen. If the particles are taken out directly, they are dried and kept in the dark before analysis [31].

The size of the particles maintained and also the filterable volume is a direct consequence of the mesh used. The meshes used for sampling in previous studies have changed between $50 \mu \mathrm{m}$ and $3000 \mu \mathrm{m}$ [31]. Another factor influencing the filtered volume is the size of the net, i.e. the sector, which acts as a filter. Seasons with tides or red flowers of plankton and jellyfish are generally unfavorable for the withdrawal of large volumes of water. Nets are usually $3-4.5 \mathrm{~m}$ long and a mesh size of around $300 \mu \mathrm{m}$ is most commonly used. These nets do not collect micro plastic particles <300 $\mu \mathrm{m}$ quantitatively but take into account the withdrawal of larger volumes of water. The non-standardized use of different nets and meshes seriously impedes the comparability of data on pelagic micro plastic concentrations [32]. Besides common net sampling, other techniques are occasionally used to assess microplastic concentrations in the water column: bulk sampling with sequenced filtration [24; 33]. Continuous Plankton Recorder (CPR) screening [21], or using direct in situ filtration [34].

A highly promising technique, currently under development, is the use of the direct fractional pressure filter of large $\left(>1 \mathrm{~m}^{3}\right)$ water volumes by a filter cascade (developed by Technologie $\mathrm{GmbH}$ of $-4 \mathrm{~h}$-jena). This approach theoretically takes into account the simultaneous removal of different size fractions of microplastics downwards and thus allows a more complete resolution of the size spectrum. 

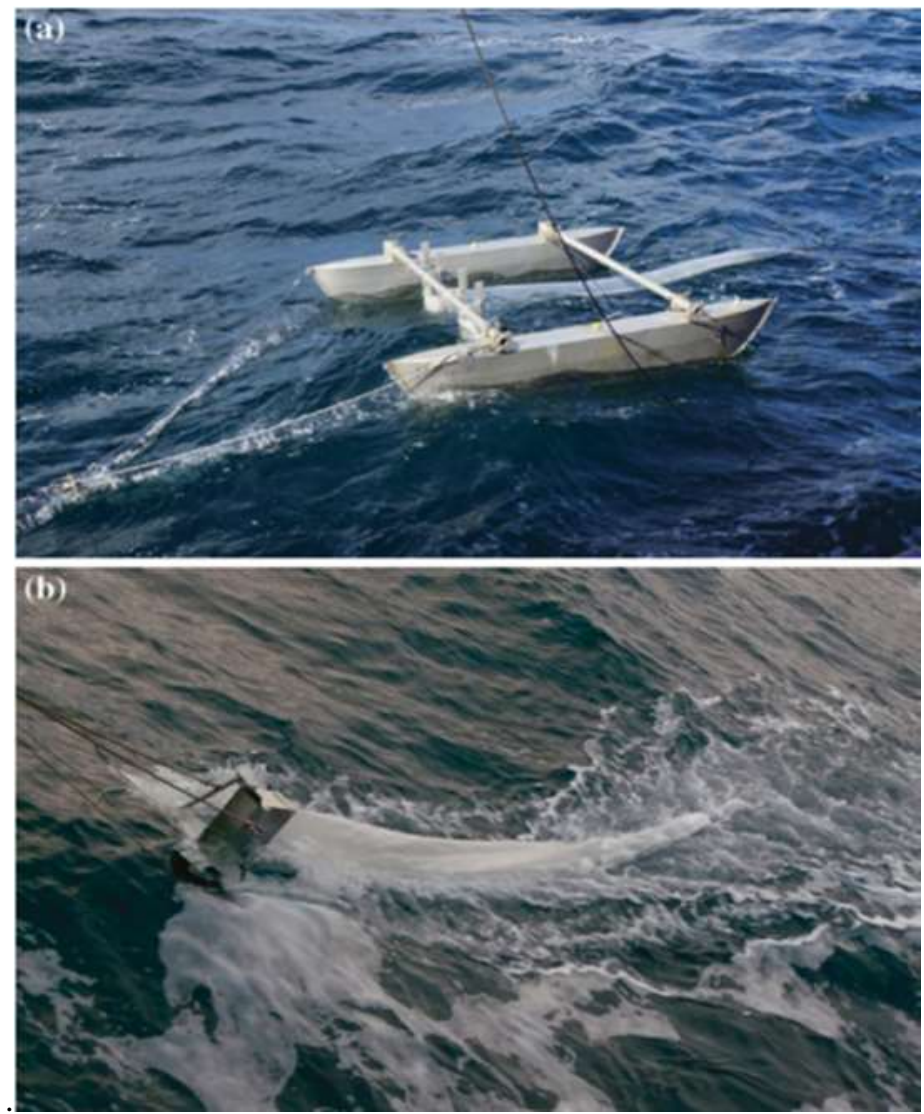

Figure 2: Catamaran neuston (a) Manta (b) [20].

\subsection{Quantity of micro plastics in marine biota}

Marine organisms are known to ingest micro plastic particles. A good part of the commercialized marine catches (fish, bivalves, crustaceans, etc.) are known to contain particles of micro plastics, with several possible routes via the mouth for example and therefore the digestive system or via the gills [35].

\subsubsection{Bivalves}

Bivalves such as mussels are suspension feeders that can filter about 2 liters of seawater per hour [36] and therefore, it is not surprising that they contain particles of micro plastics. Cultured mussels showed lower proportions of micro plastics than wild mussels when collected, and a large part of these contaminants consist of plastic cord [37].

Another study of blue mussels cultivated in Germany (the North Sea) and oysters cultivated from Brittany, France (North Atlantic), showed that both species contained micro plastics, i.e. $0.36 \pm 0.07$ particles / g-1 ( wet weight) and $0.47 \pm 0.16$ particles / g-1 (wet weight) respectively [38]. The significance of micro plastic pollution on seafood safety is not known, although it is important to note that the concentrations determined in mussels and cultivated oysters are relatively low [38].

\subsubsection{Crustaceans}

Barnacles (crustaceans) which are sessile marine organisms also living in the intertidal zone. are like mussels, they are suspensivores and therefore it is not surprising that $33.5 \%$ of North Pacific barnacles contain particles of micro plastics. The average number of microplastic particles is typically between 1 and 30 [39]. In Clyde Bay (west coast of Scotland) 83\% of Nephrops norvegicus found were contaminated with micro plastic particles and $62 \%$ of these particles were present as tightly entangled beads (Figure 3) [40].

Langoustines are omnivorous and therefore consume a lot of different benthic fauna such as crustaceans, polychaetes, bivalves and the ingestion of the plastic particles is likely to be due via the food or passively from the sediment when 'they feed [40]. 


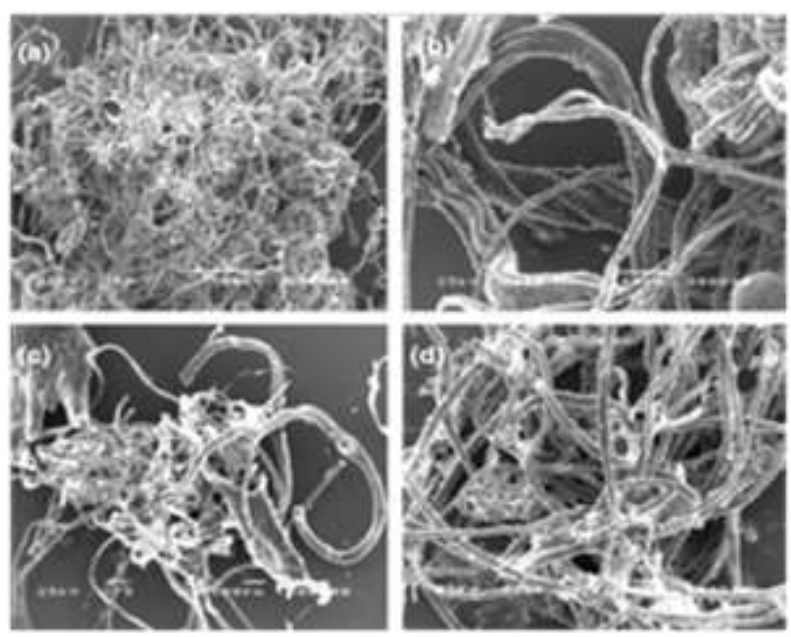

Figure 3: Image of micro plastics in $\mathbf{N}$ norvegicus by scanning electron microscopy [40].

\subsubsection{Fish}

While the first ingestion of plastic by fish was reported by [41], research on this topic is recent. According to several studies, the types of plastics ingested differ according to species and regions [42]. Fish from the English Channel appear to be exposed, but this has only been confirmed by three studies focused on seas in northern Europe [43; 17; 44]. In the North Sea, [43] reported that $2.6 \%$ of the fish collected contained plastic in their stomach.

In another report, [17] highlighted that the majority of polymer particles were fibers. Of the 351 pieces of polymer found, 58\% were radiated. Another study indicating plastic ingestion by fish in northern Europe found 21 plastics in 290 fish [44], Polyethylene was the most registered polymer.

In the Mediterranean Sea, elasmobranchs appeared to be more exposed than the teleost species [45]. 3\% of elasmobranchs ingested plastic debris, which accounts for $86.5 \%$ of all ingested debris. Other studies in the Mediterranean Sea reporedt a higher percentage of ingestion $[45 ; 46 ; 47 ; 48 ; 46]$. All three species ingested micro and macro-plastics with a similar color tendency: transparent, white, yellowish and blue particles being preferentially ingested.

In another study, [47] reported an ingestion frequency of $24 \%$ in Trachinotus ovatus and the same color trend was found. The highest frequency of ingestion occurred in Boops boops (58\%) but no dominant color was reported [48].

\subsection{Methods of isolating micro plastics}

Majority of the methods have been examined and validated on mussel tissues or stomach contents of fish (Table 3). However, few studies employ chemical methods to isolate micro plastic particles. The most common isolation method is the digestion of organic matter with a $10 \%$ solution of potassium hydroxide $(\mathrm{KOH})$ first described by [43].

Table 3: Summary of methods for isolating plastics from biological samples

\begin{tabular}{|c|c|c|c|c|}
\hline Samples & Chemical & Advantages & Pitfalls & References \\
\hline $\begin{array}{l}\text { Mussel soft } \\
\text { tissues }\end{array}$ & $\mathrm{HNO}_{3}$ & Cheap and quick & $\begin{array}{l}\text { Polyamide fibers not recovered, tested by } \\
\text { [51].with low recovery }\end{array}$ & [27]. \\
\hline $\begin{array}{l}\text { Mussel soft } \\
\text { tissues }\end{array}$ & $\begin{array}{l}\mathrm{HNO}_{3}: \mathrm{HCLO}_{4} \quad(4: 1 \\
\mathrm{v}: \mathrm{v})\end{array}$ & Cheap and quick & $\begin{array}{l}\text { No information available on the } \\
\text { resistance of plastic polymers }\end{array}$ & [49]. \\
\hline Plankton & Enzyme (Proteinase-K) & Cheap and quick & Expensive & {$[50]$. } \\
\hline $\begin{array}{l}\text { Stomach } \\
\text { content fish }\end{array}$ & Rose bengal stain & Cheap & $\begin{array}{l}\text { Based on visual } \\
\text { sorting }\end{array}$ & {$[3]$. } \\
\hline $\begin{array}{l}\text { Stomach } \\
\text { content fish }\end{array}$ & $\mathrm{KOH}$ & Cheap & $\begin{array}{l}\text { Time consuming, polycarbonate and } \\
\text { polyamide not resistant }\end{array}$ & [43]. \\
\hline $\begin{array}{l}\text { Stomach } \\
\text { content fish }\end{array}$ & $\begin{array}{l}\mathrm{NaCl} \text { (density gradient } \\
\text { separation) and } \mathrm{H}_{2} \mathrm{O}_{2}\end{array}$ & Cheap and quick & $\begin{array}{l}\text { Validated on } 2 \\
\text { polymers }\end{array}$ & [51]. \\
\hline
\end{tabular}




\section{RESULTS AND DISCUSSION}

From a qualitative and quantitative point of view, and using a scanning electron microscope, plastic debris ingested by organisms (Pseudotolithus sp and E. fimbriata) were classified into five groups: (a) fishing lines (47\%), (b) plastic particles (9\%), (c) cord filaments (23\%) (d) thongs (13\%), and (e) other particles (8\%) (Figure 4). The result is in line with [52], who used two species of coral trout as one single group for data analyses, given their similarities in life history, diet and feeding strategies.
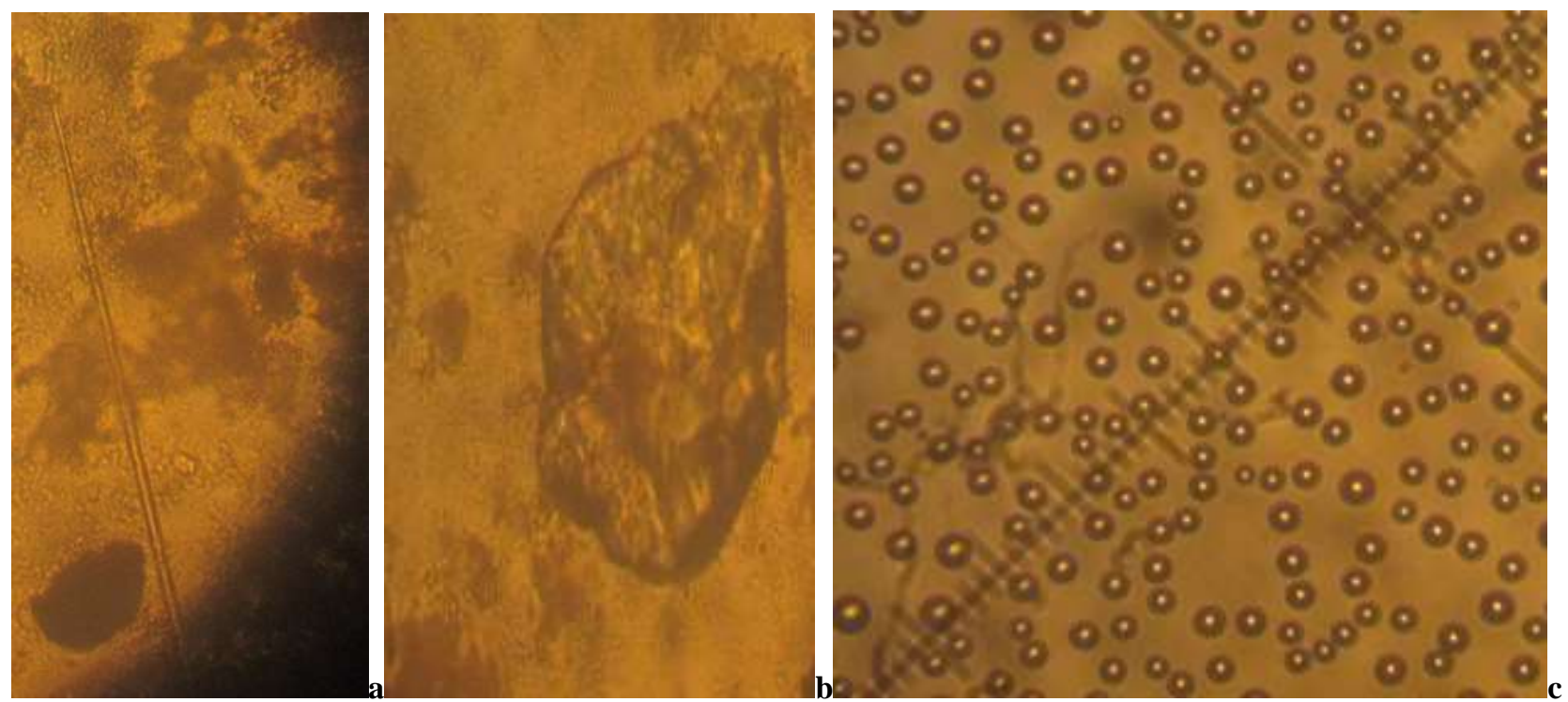

Figure 4 :Micro plastics found in the samples (a) fishing line, (b) plastic particle, (c) cord filaments

\section{CONCLUSION}

The present Classification study of Ingested Plastic Particles using electron microscopy in a laboratory data analysis allowed us to obtain information on the quality and quantity of ingested micro plastic particles by two marine species Pseudotolithus sp and E. fimbriata). The results from this study will certainly enhance policy development where protein from fish is considered the ultimate source for protein for humankind, not forgetting fish pollution which is a common cry to communities that depend on fish for their income and livelihoods.

\section{REFERENCES}

1. Wright S.L., Thompson R.C., Galloway T.S., (2013). The physical impacts of microplastiques on marine organisms: A review. Environmental Pollution, 178, 483-492.

2. Collignon A., Hecq J.H., Glagani F., Voisin P., Collard F \& Goffart A., 2012. Neustonic microplastic and zooplankton in the North Western Mediterranean Sea. Marine pollution bulletin, 64(4): 861-864.

3. Davidson P., et Asch R.G., 2011. Plastic ingestion by mesopelagic fishes in the North Pacific Subtropical Gyre. Marine Ecology Progress Series, 432: 173-180.

4. Cózar A., et Echevarría ., 2014. Plastic debris in the open ocean. Proceedings of the National Academy of Sciences, 111 (28): 10239-10244.

5. Lithner D., Larsson A \& Dave G., 2011. Environmental and health hazard ranking and assessment of plastic polymers based on chemical composition. Sci. Total Environ. 409: 3309e3324.

6. Teuten E., Saquing J., Knappe D., Barlaz M., Jonsson S., 2009. Transport and release of chemicals from plastics to the environment and to wildlife. Phil. Trans. R. Soc. B 364: 2027e2045.

7. Bowmer T., Kershaw P., 2010. Proceedings of the GESAMP International Workshop on microplastic particles as a vector in transporting persistent, bioaccumulating and toxic substances in the oceans. 28-30th June 2010, UNESCO-IOC, Paris. GESAMP Rep. Stud. 82.

8. Kenyon K.W., Kridler E., 1969. Laysan Albatrosses Swallow Indigestible Matter. The Auk 86, $339-343$. doi:10.2307/4083505.

9. Laist D.W., 1997. Impacts of Marine Debris: Entanglement of Marine Life in Marine Debris Including a Comprehensive List of Species with Entanglement and Ingestion Records, in: Coe, J.M., Rogers, D.B. (Eds.), Marine Debris, Springer Series on Environmental Management. Springer New York, pp. 99-139.

10. Andrady A.L., 2011. Microplastiques in the marine environment. Mar. Pollut. Bull. 62: 1596-1605. 
11. Masó M., Garcés E., Pagès F \& Camp J., 2007. Drifting plastic debris as a potential vector for dispersing Harmful Algal Bloom (HAB) species. Sci. Mar. 67: 107-111.

12. Folack J., 2001. Analyse transfrontalière pour la région du golfe de Guinée, Rapport consultation UNIDO/PNUD/PNUE : NOAA, projet Grand Ecosystème Marin du Courant de Guinée (GEM-CG), 36pages.

13. Njifonjou O., 1999. Enquête-cadre sur la pêche artisanale maritime dans la région «modèle» du Fako, Projet TCP/CMR/8821, FAO, 19p

14. ENVI-REP CAMEROUN., 2011. Mise en œuvre de la Gestion Intégrée des Zones Côtières (GIZC) pour la région de Kribi-campo au Cameroun. Rapport final, Texte principal, 221p.

15. Olivier M.J., 2012. Chimie de l'environnement. 7e édition, Lévis (Québec), Les productions Jacques Bernier, 444 p.

16. MINEP., 2008. Rapport sur l'état de la biodiversité marine et côtière au Cameroun, juillet 2008. 18 pages.

17. Lusher A., 2015. Microplastiques in the marine environment: distribution, interactions and effects. In M. Bergmann, L. Gutow \& M. Klages (Eds.), Marine anthropogenic litter (pp. 245-308). Springer, Berlin in Löder M.G.J. \& Gunnar G., 2015. Methodology Used for the Detection and Identification of Microplastiques: A Critical Appraisal. Chapter 8. Marine Anthropogenic Litter, doi 10.1007/978-3-319-16510-3_8

18. Ivar do Sul J.A., \& Costa M.F., 2013. The present and future of microplastic pollution in the marine environment. Environmental Pollution, 185, 352-364.

19. Cole M., Lindeque P., Fileman E., Halsband C., Goodhead R., Moger J., 2013. Microplastic ingestion by zooplankton. Environmental Science and Technology, 47(12), 6646-6655.

20. Löder M.G.J. \& Gunnar G., 2015. Methodology Used for the Detection and Identification of Microplastiques: A Critical Appraisal. Chapter 8. Marine Anthropogenic Litter, doi 10.1007/978-3-319-16510-3_8

21. Thompson R.C., Olsen Y., Mitchell R.P., Davis A., Rowland S.J., John A.W.G.,McGonigle D., Russell A.E., 2004. Lost at sea: where is all the plastic? Science 304, 838.

22. Plastics Europe., 2012. Plastics - the Facts 2012. An Analysis of European Plastics Production; Demand and Waste Data for 2011. Plastics Europe, Association of Plastic Manufacturers,Brussels, p. 38.

23. Reddy M.S., Basha S., Adimurthy S., Ramachandraiah G., 2006. Description of the small plastics fragments in marine sediments along the Alang-Sosiya shipbreaking yard, India. Estuar. Coast. Shelf Sci. 68, 656-660.

24. Ng K.L., Obbard J.P., 2006. Prevalence of microplastiques in Singapore's coastal marine environment. Mar. Pollut. Bull. 52, 761-767.

25. Browne M.A., Crump P., Niven S.J., Teuten E., Tonkin A., Galloway T.S., Thompson R.C., 2011. Accumulation of microplastic on on shorelines worldwide: sources and sinks. Environ. Sci. Technol. 45, 9175-9179.

26. Claessens M., De Meester S., Van Landuyt L., De Clerck K., Janssen C.R., 2011. Occurence and distribution of microplastiques in marine sediments along the Belgian coast. Mar. Pollut. Bull. 62, 2199-2204.

27. Claessens M., Cauwenberghe L.V., Vandegehuchte M.B., Janssen C.R., 2013. New techniques for the detection of microp lastics in sedime nts and field colle cted organisms . Mar. Pollut. Bull. (2013), http ://dx.doi. org/10.1016/ j.marpolbu 1.2013.0 3.009.

28. Fettweis, X., van Ypersele, J.-P., Gallee, H., Lefebre, F., and Lefeb- ' vre, W.: The 1979-2005 Greenland ice sheet melt extent from passive microwave data using an improved version of the melt retrieval XPGR algorithm, Geophys. Res. Lett., 34, L05502, doi:10.1029/2006GL028787, 2007.

29. Doyle M., Watson W., Bowlin N.M., \& Sheavly S.B., 2011. Plastic particles in coastal pelagic ecosystems of the Northeast Pacific Ocean. Marine Environmental Research, 71(1), 41-52.

30. Morét-Ferguson S., Law K.L., Proskurowski G., Murphy E.K., Peacock, E.E., \& Reddy, C.M., 2010. The size, mass, and composition of plastic debris in the Western North Atlantic Ocean. Marine Pollution Bulletin, 60 (10), $1873-1878$.

31. Hidalgo-Ruz V., Gutow L., Thompson R. C., \& Thiel M., 2012. Microplastics in the marine environment: A review of the methods used for identification and quantification. Environmental Science and Technology, 46 (6), 3060-3075.4

32. Löder M.G.J. \& Gunnar G., 2015. Methodology Used for the Detection and Identification of Microplastiques: A Critical Appraisal. Chapter 8. Marine Anthropogenic Litter, doi 10.1007/978-3-319-16510-3_8

33. Dubaish F., \& Liebezeit G., 2013. Suspended microplastics and black carbon particles in the Jade system, Southern North Sea. Water, Air, and Soil pollution, 224(2), 1-8.

34. Norén F., \& Naustvoll L.J., 2010. Survey of microscopic anthropogenic particles in Skagerrak. Klima- og forurensningsdirektoratet TA, 2779-2011, 1-20.

35. Nerland I.L., Halsband C., Allan I., Thomas K.V., 2014. Microplastics in marine environments: occurrence, distribution and effects. Norwegian Institute for Water Research., Report SNO. 6754-2014., 71pp.

36. Durve V. S., 1963. A study on the rate of filtration of the clam Meretrix Casta (CHEMNITZ).

37. Mathalon A \& Hill P., 2014. Microplastic fibers in the intertidal ecosystem surrounding Halifax Harbor, Nova Scotia. Mar. Pollut. Bull. 81, 69-79. 
38. Van Cauwenberghe L. \& Janssen C.R., 2014. Microplastics in bivalves cultured for human consumption. Environ. Pollut. 193, 65-70.

39. Goldstein M \& Goodwin D., 2013. Gooseneck barnacles (Lepas spp.) ingest microplastic debris in the North Pacific Subtropical Gyre. PeerJ 1:e184 (2013). At http://dx.doi.org/10.7717/peerj.184.

40. Murray F \& Cowie P.R., 2011. Plastic contamination in the decapod crustacean Nephrops norvegicus (Linnaeus, 1758). Mar. Pollut. Bull. 62, 1207-1217.

41. Carpenter E.J., Smith Jr K.L., 1972. Plastics on the Sargasso sea surface. Science (80). 175,1240-1241.

42. Rochman C.M., Hoh E., Kurobe T., Teh S.J., 2013. Ingested plastic transfers hazardous chemicals to fish and induces hepatic stress. Sci. Rep. 3. doi:10.1038/srep03263 http://www.nature.com/srep/2013/131121/srep03263/abs/srep03263.html\#suppleme ntary-information

43. Foekema E.M., de Gruijter C., Mergia M.T., 2013. Plastic in North Sea Fish. Environ Sci Technol 2013; 47:8818-24.

44. Rummel C.D., Löde, M.G.J., Fricke N.F., Lang T., Griebeler E.M., Janke M., Gerdts G., 2016. Plastic ingestion by pelagic and demersal fish from the North Sea and Baltic Sea. Mar. Pollut. Bull. 102, 134-141. doi:10.1016/j.marpolbul.2015.11.043.

45. Anastasopoulou A., Mytilineou C., Smith C.J., Papadopoulou K.N., 2013. Plastic debris ingested by deep-water fish of the Ionian Sea (Eastern Mediterranean). Deep. Res. Part I Oceanogr. Res. Pap. 74, 11-13.

46. Romeo T., Pietro B., Pedà C., Consoli P., Andaloro F., Fossi M.C., 2015. First evidence of presence of plastic debris in stomach of large pelagic fish in the Mediterranean Sea. Mar. Pollut. Bull. 95, 358-361. doi:10.1016/j.marpolbul.2015.04.048.

47. Battaglia P., Pedà C., Musolino S., Esposito V., Andaloro F., Romeo T., 2016. Diet and firstdocumented data on plastic ingestion of Trachinotus ovatus L. 1758 (Pisces: Carangidae) from the Strait of Messina (central Mediterranean Sea). Ital. J. Zool. 83, 121-129. doi:10.1080/11250003.2015.1114157.

48. Nadal M.A., Alomar C., Deudero S., 2016. High levels of microplastic ingestion by the semipelagic fish bogue Boops boops (L.) around the Balearic Islands. Environ. Pollut.214, 517-523. doi:10.1016/j.envpol.2016.04.054.

49. De Witte B., Devriese L., Bekaert K., Hoffman S., Vandermeersch G., Cooreman K., Robbens J., 2014. Quality assessment of the blue mussel (Mytilus edulis): Comparison between commercial and wild types. Mar. Pollut. Bull. 85, 146-155. doi:10.1016/j.marpolbul.2014.06.006.

50. Cole M., Webb H., Lindeque P.K., Fileman E.S., Halsband C., Galloway T.S., 2014. Isolation of microplastics in biotarich seawater samples and marine organisms. Sci. Rep. 4.

51. Avio C.G., Gorbi S., Milan M., Benedetti M., Fattorini D., d'Errico G., Pauletto M., Bargelloni L., Regoli F., 2015. Pollutants bioavailability and toxicological risk from microplastics to marine mussels. Environ. Pollut. 198C, $211-222$. doi:10.1016/j.envpol.2014.12.021.

52. Kailola, P. J. et al. Fisheries Resources. 422 (Bureau of Resource Sciences, Department of Primary Industries and Energy, and the Fisheries Research and Development Corporation, 1993). 